Commun. Fac. Sci. Univ. Ank. Series C

V. 5, pp 31-37 (1987)

\title{
A NEW RECORD OF PIPISTRELLUS PIPISTRELLUS ALADIDN FOR TURKEY
}

\section{ALBAYRAK}

Department of Biology, Faculty of Sciences, University of Ankara

\begin{abstract}
Between April 1977 and November 1981, during taxonomical researches on Turkish bats in Eastern Turkey, the presence of Pipistrellus pipistrellus aladdin Thomas, 1905, was first recorded from Turkey.

This study is based on a total of 163 specimens comprising 131 Pipistrellus pipistrellus pipistrellus (Schreber, 1774) and 32 P. p. aladdin. Out of 131 specimens, 81 were obtained from Western Turkey and used only for the determination of the distribution map of P.p. pipistrellus in this paper.
\end{abstract}

Field notes were also recorded. Weight and 37 external and cranial measurements were taken, they were used for comparison and statistical evaluation.

The results revealed that two subspecies of $\boldsymbol{P}$. pipistrellus, the nominate form and $\boldsymbol{P}$. $\boldsymbol{p}$. aladdin exist in Turkey.

\section{INTRODUCTION}

Ellerman and Morrison-Scott (1951) noted that the distribution area of $P$. p. pipistrellus has included Asia Minor (Anatolia). Lewis and Harrison (1962) recorded the specimens (Nat. Hist. B.M.) from Chankan as the nominate form. Lehmann (1966) recorded the four specimens from Bedirge near Antakya as $P . p$. mediterraneus Cabrera, 1904. Neuhauser and DeBlase (1971) stated that two specimens (Nat. Hist. B.M.) from Yalnız near Antalya represented the nominate form. Corbet (1978) also confirmed that Asia Minor (Anatolia) was in the distribution area of $P$. p. pipistrellus

As a native research - maker I intended to revise and clarify the situation in this study. 


\section{MATERIAL AND METHOD}

During our researches, between April 1977 and November 1981, I obtained 82 specimens of Pipistrellus pipistrellus in Eastern Turkey and prepared them in the conventional museum type according to Mursaloğlu. (1965).

As all of the female specimens except one were obtained from the breeding colonies, the majority of females were either pregnant or nursing adult. Therefore, all comparisons were made between only these adult females.

All the measurements were taken according to Thomas (1905b), Harrison (1964) and Albayrak (1985). Weight and 37 external and cranial measurements taken from each specimen were compared and statistically evaluated. For comparison the specimens were divided into age groups: infants, juveniles and adults according to the procedures of Andersen (1917) and Baagoe (1977). Only adult were taken into consideration.

To obtain the distribution area of $\boldsymbol{P}$. p.pipistrellus in entire Turkey, I considered 81 specimens obtained from the other part of Turkey but their statistical data were not used.

All of the specimens have been deposited in the mammalian collection of the Department of Biology, Faculty of Science, University of Ankara.

\section{RESULTS}

Out of the 163 specimens, 131 were presenting the nominate form and 32 P. p. aladdin.

Pipistrellus pipistrellus pipistrellus (Schreber, 1774)

1774. Vespertilio pipistrellus (Schreber, Säugethiere, 1: 67.

Type locality: France.

1897. Pipistrellus pipistrellus, Miller, Ann. Mag. Nat. Hist., 6 (20): $384-385$.

Our specimens have the same diagnostic characters as colour and colour pattern recorded before by Schreber (1774). 


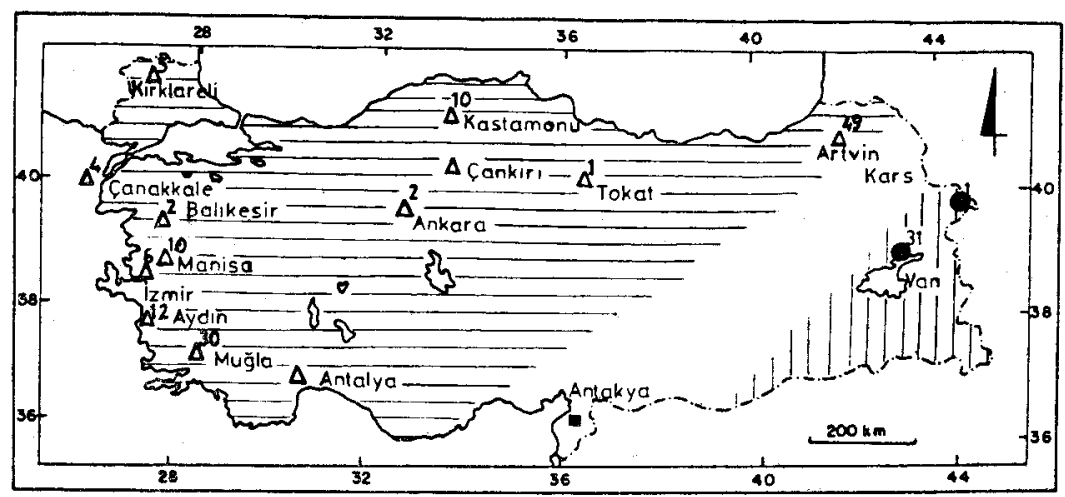

Fig. 1. Map of Turkey showing the collection localities and tbe approximate distribution of $P . p$. pipistrellus $(\Delta)$ and $P . p$. aladdin (O). The distribution of $P . p$. pipistrellus (三) and P.p. aladdin (ill), the previos record of $P$.p. mediterraneus ( $\square$ ) and the transition area $\square$ between $P$.p. pipistrellus and P.p. aladdin.

Four external and seven cranial measurements given by Miller (1912) for P. p. pipistrellus agreed with the measurements (see Table 1) of our specimens.

Habitat: 49 specimens were collected in a very narrow space between the walls of two buildings in Artvin and another one was netted during a low flight in the field in Tokat at night.

During mid-July the colonies were consisting of 40-50 individuals. Adult females were either pregnant haring twin embrios or nursing mother with twin infants. The colonies did not include adult males.

The daily flight would begin after sunset.

The identification of my specimens obtained from the Western, Middle and Northeast Turkey showed that the distribution of $P . p$. pipistrellus covers the whole Western, Middle and Norteast Turkey (Fig. 1)

Specimens examined: Total number, 144 from the following localities: Bahkesir province, Dinkçiler district $(1$ adult and 1 adult ô, 18/6/1977); Tokat province, Turhal city, Pazar town (1 juvenile , 12/8/ 1978); Ankara province, Çankaya (2 adalt $q$ ㅇ, 23/9/1978); Artvin province, Hotel Genya (22 adult $q$ ㅇ, 14 juvenile $q$ 우 and 13 juvenile ડ̂ô, 16/7/1979); Çanakkale province, Gökçeada (1 adult $\&, 3$ 
Table 1. The statistical data of external and cranial measurements of adult P.p.pipistrellus: number of individuals $(N)$, range $(R)$, mean $(X)$ and standart deviations ( $\pm S d$ ).

\begin{tabular}{|c|c|c|c|c|}
\hline 웅 Measurements & $\mathbf{N}$ & $\overline{\mathbf{R}}$ & $\bar{X}$ & $\pm \mathrm{Sd}$ \\
\hline Total length & 22 & $75-87$ & 80.0 & 3.23 \\
\hline Length of head and body $\ldots \ldots \ldots \ldots$ & 22 & $43-55$ & 49.4 & 2.65 \\
\hline Length of tail $\ldots \ldots \ldots \ldots \ldots \ldots$ & 22 & $28-33$ & 30.7 & 1.56 \\
\hline Length of hindfoot $\ldots \ldots \ldots \ldots \ldots \ldots$ & 22 & $8-9$ & 8.7 & 0.45 \\
\hline Length of ear $\ldots \ldots \ldots \ldots \ldots \ldots \ldots$ & 22 & $8.5-11$ & 10.1 & 0.76 \\
\hline Length of tragus $\ldots \ldots \ldots \ldots \ldots \ldots \ldots \ldots \ldots$ & 14 & $4-6-5.4$ & 5.1 & 0.24 \\
\hline Length of forearm ... & 15 & $29.8-32.4$ & 30.8 & 0.84 \\
\hline$\ldots \ldots \ldots \ldots \ldots$ & 15 & $9.4-10.7$ & 10.1 & 0.37 \\
\hline 2nd metacarpal length & 15 & $27.3-29.6$ & 28.2 & 0.67 \\
\hline 3rd metacarpal length & 15 & $28.2-30.5$ & 29.4 & 0.68 \\
\hline Length af Ist phalange of 3rd digit $\ldots \ldots \ldots$ & 15 & $10.4-11.7$ & 11.0 & 0.41 \\
\hline Length of 2 nd phalange of 3 rd digit . . . . . & 15 & $7.7-9.3$ & 8.4 & 0.45 \\
\hline 4th metacarpal length $\ldots \ldots \ldots \ldots \ldots \ldots$ & 15 & $28-30$ & 29.0 & 0.58 \\
\hline Length of 1st phalange of 4 th digit $\ldots \ldots \ldots$ & 15 & $9.7-10.8$ & 10.3 & 0.35 \\
\hline Length of 2 nd phalange of 4 th digit $\ldots \ldots$ & 15 & $5.7-7.1$ & 6.2 & 0.41 \\
\hline 5th metacarpal length $\ldots \ldots \ldots \ldots \ldots \ldots$ & 15 & $27.0-29.4$ & 28.0 & 0.73 \\
\hline Length of 1st phalange of 5 th digit $\ldots \ldots \ldots$ & 15 & $6.4-7.4$ & 6.8 & 0.30 \\
\hline Length of 2 nd phalange of 5 th digit $\ldots \ldots \ldots$ & 15 & $3.3-4.3$ & 3.8 & 0.27 \\
\hline Greatest length of skull $\ldots \ldots \ldots \ldots \ldots \ldots$ & 22 & $11.8-12.7$ & 12.3 & 0.25 \\
\hline Total length of skull & 22 & $11.4-12.3$ & 11.9 & 0.25 \\
\hline Condylobasal length $\ldots \ldots \ldots \ldots \ldots \ldots \ldots$ & 22 & $10.8-11.8$ & 11.3 & 0.26 \\
\hline Basal length $\ldots \ldots \ldots \ldots \ldots \ldots \ldots$ & 21 & $9.9-10.7$ & 10.4 & 0.24 \\
\hline Palatal length $\ldots \ldots \ldots \ldots \ldots \ldots \ldots$ & 21 & $3.6-4.4$ & 4.0 & 0.21 \\
\hline$\ldots \ldots \ldots \ldots \ldots \ldots \ldots$ & 22 & $2.9-3.4$ & 3.1 & 0.12 \\
\hline Zygomatic breadth $\ldots \ldots \ldots \ldots \ldots \ldots \ldots$ & 21 & $7.2-7.7$ & 7.4 & 0.14 \\
\hline Interorbital constriction $\ldots \ldots \ldots \ldots \ldots \ldots$ & 22 & $3,3-3,7$ & 3.5 & 0.11 \\
\hline Breadth of braincase $\ldots \ldots \ldots \ldots \ldots \ldots$ & 22 & $6.1-6.5$ & 6.3 & 0.12 \\
\hline Mastoid breadth $\ldots \ldots \ldots \ldots \ldots \ldots \ldots$ & 22 & $6.3-6.8$ & 6.6 & 0.11 \\
\hline Rostral breadth $\ldots \ldots \ldots \ldots \ldots \ldots \ldots$ & 21 & $3.4-3.8$ & 3.6 & 0.10 \\
\hline Infraorbital breadth & 22 & $3.5-4.0$ & 3.7 & 0.13 \\
\hline Height of skull $\ldots \ldots \ldots \ldots \ldots \ldots \ldots \ldots$ & 20 & $5.2-5.7$ & 5.5 & 0.15 \\
\hline Length of maxillary toothrow .. & 21 & $4.1-4.5$ & 4.2 & 0.11 \\
\hline Length of upper molar ........... & 21 & $2.6-2.9$ & 2.7 & 0.10 \\
\hline Length of mandibular toothrow ...... & 22 & $4.2-4.7$ & 4.5 & 0.13 \\
\hline Length of lower molar $\ldots \ldots \ldots$ & 22 & $2.8-3.3$ & 3.1 & 0.13 \\
\hline Length of mandible .. & 21 & $7.9-8.8$ & 8.4 & 0.25 \\
\hline Diameter of tympanic bulla & 20 & $2.6-3.1$ & 2.9 & 0.13 \\
\hline Weight $(g) \ldots \ldots \ldots \ldots \ldots \ldots \ldots \ldots \ldots$ & 22 & $3.5-5.0$ & 4.5 & 0.53 \\
\hline
\end{tabular}

adult $\widehat{\jmath} \hat{\delta}, 12 / 9 / 1983)$; İzmir province, Çeşme city, Alaçatı town (6 adult $q$ $q$, 25/8/1984); Kastamonu province, Araç city (10 adult $q$, $18 / 8 / 1984$ ); Aydın province, Kuşadası city (12 adult $q$ \& , $13 / 6 / 1985$; Kirklareli province, Alpullu city ( 4 adult $q$ ㅇ, 1 adult $\delta, 8 / 7 / 1985)$; Manisa province, Muradiye town (10 adult $\left.{ }_{+}+14 / 6 / 1985\right)$ and Muğla province, Dalyan town, Ortaca (30 adult 우 ㅇ, 26/5/1985).

Pipistrellus pipisturellus aladdin thomas, 1905

1905. Pipistrellus aladdin Thomas, Proc. Zool. Soc., London, 2: 521.

Typeo lcality: $75 \mathrm{~km}$. Wst of Islahan, Iran.

1971. Pipistrellus pipistrellus aladdin, Neuhauser and DeBlase Mammalia, 35 (2): 273-282. 
Table 2. The statistical data of external and cranial measurements of adult P.p. aladdin: number of individuals $(N)$, range $(R)$, mean $(X)$ and standart deviations $( \pm S d)$.

\begin{tabular}{|c|c|c|c|c|}
\hline 9 Measurements & $\mathbf{N}$ & $\mathbf{R}$ & $\mathbf{X}$ & $\pm \mathrm{Sd}$ \\
\hline Total length & 30 & $83-92$ & 87.0 & 2.20 \\
\hline Length of head and body $\ldots \ldots \ldots \ldots \ldots$ & 30 & $50-57$ & 54.0 & 1.97 \\
\hline Length of tail $\ldots \ldots \ldots \ldots \ldots \ldots \ldots$ & 30 & $30-37$ & 33.0 & 1.40 \\
\hline Length of hindfoot $\ldots \ldots \ldots \ldots \ldots \ldots$ & 31 & $7.0-8.5$ & 7.9 & 0.38 \\
\hline Length of ear $\ldots \ldots \ldots \ldots \ldots \ldots \ldots$ & 31 & $9-12$ & 10.7 & 0.84 \\
\hline Length of tragus $\ldots \ldots \ldots \ldots \ldots \ldots$ & 25 & $4.5-6.5$ & 5.5 & 0.53 \\
\hline Length of forearm & 31 & 29-33 & 31.4 & 0.99 \\
\hline Length of tibia $\ldots \ldots \ldots \ldots \ldots \ldots \ldots$ & 17 & $10.0-11.7$ & 10.9 & 0.48 \\
\hline 2nd metacarpal length $\ldots \ldots \ldots \ldots \ldots \ldots$ & 18 & $27.5-30.5$ & 28.8 & 0.90 \\
\hline 3rd metacarpal length $\ldots \ldots \ldots \ldots \ldots \ldots$ & 18 & $29.0-31.6$ & 30.3 & 0.72 \\
\hline Length of lst phalange of ${ }^{2}$ rd digit $\ldots \ldots \ldots$ & 18 & $10.5-12.6$ & 11.5 & 0.58 \\
\hline Length of and phalange of 3 rd digit . . . . . . & 18 & $7.7-9.6$ & 8.8 & 0.45 \\
\hline 4th metacarpal length $\ldots \ldots \ldots \ldots \ldots \ldots$ & 18 & $28.3-31.5$ & 29.9 & 0.91 \\
\hline Length $f$ Ist phalange of 4 th digit ........ & 18 & $10.2-11.6$ & 10.9 & 0.42 \\
\hline Length of 2 nd phalange of 4 th digit . . . . . . & 18 & $5.8-7.3$ & 6.6 & 0.36 \\
\hline 5 th metacarpal length $\ldots \ldots \ldots \ldots \ldots \ldots$ & 18 & $27.4-30.6$ & 28.8 & 0.92 \\
\hline Length of lst phalange of 5 th digit $\ldots \ldots \ldots$ & 18 & $6.2-8.0$ & 7.3 & 0.45 \\
\hline Length of 2 nd phalange of 5 th digit $\ldots \ldots \ldots$ & 18 & $3.6-4.8$ & 4.1 & 0.31 \\
\hline Greatest length of skull $\ldots \ldots \ldots \ldots \ldots$ & 30 & $12.0-12.9$ & 12.5 & 0.23 \\
\hline Total length of skull $\ldots \ldots \ldots \ldots \ldots \ldots \ldots$ & 30 & $11.6-12.9$ & 12.2 & 0.27 \\
\hline Condylobasal length $\ldots \ldots \ldots \ldots \ldots \ldots$ & 30 & $11.3-12.1$ & 11.7 & 0.22 \\
\hline$\ldots \ldots \ldots \ldots \ldots \ldots$ & 30 & $10.3-11.0$ & 10.7 & 0.20 \\
\hline Palatal length $\ldots \ldots \ldots \ldots \ldots \ldots \ldots \ldots \ldots$ & 27 & $3.6-4.2$ & 3.9 & 0.20 \\
\hline Rostral length $\ldots \ldots \ldots \ldots \ldots \ldots \ldots \ldots$ & 31 & $3.0-3.6$ & 3.3 & 0.15 \\
\hline Zygomatic breadth $\ldots \ldots \ldots \ldots \ldots \ldots \ldots$ & 20 & $7.3-7.9$ & 7.6 & 0.14 \\
\hline Interorbital constriction $\ldots \ldots \ldots \ldots \ldots$ & 30 & $3.3-3.7$ & 3.5 & 0.10 \\
\hline Breadth of braincase .... & 30 & $6.2-6.7$ & 6.5 & 0.11 \\
\hline Mastoid breadth $\ldots \ldots \ldots \ldots \ldots \ldots \ldots$ & 31 & $6.5-7.2$ & 6.9 & 0.14 \\
\hline$\ldots \ldots \ldots \ldots \ldots \ldots \ldots \ldots$ & 30 & $3.5-3.8$ & 3.7 & 0.08 \\
\hline Infraorbital breadth $\ldots \ldots \ldots \ldots \ldots \ldots \ldots$ & 30 & $3.5-4.0$ & 3.8 & 0.11 \\
\hline Height of skull $\ldots \ldots \ldots \ldots \ldots \ldots \ldots \ldots$ & 31 & $5.5-6.0$ & 5.8 & 0.13 \\
\hline Length of maxillary toothrow $\ldots \ldots \ldots$ & 31 & $4.2-4.4$ & 4.3 & 0.07 \\
\hline Length of ppper molar $\ldots \ldots \ldots \ldots \ldots \ldots$ & 31 & $2.7-3.0$ & 2.9 & 0.09 \\
\hline Length of mandibular toothrow $\ldots \ldots \ldots \ldots$ & 31 & $4.4-4.8$ & 4.6 & 0.09 \\
\hline Length of lower molar $\ldots \ldots \ldots \ldots \ldots \ldots \ldots$ & 31. & $3.1-3.3$ & 3.2 & 0.07 \\
\hline Length of mandible $\ldots \ldots \ldots \ldots \ldots \ldots \ldots$ & 31 & $8.3-8.9$ & 8.7 & 0.16 \\
\hline Diameter of tympanic bulla .......... & 31 & $2.9-3.3$ & 3.0 & 0.11 \\
\hline Weight $(g) \ldots \ldots \ldots \ldots \ldots \ldots \ldots \ldots$ & 31 & $4.5-8.0$ & 5.5 & 0.99 \\
\hline
\end{tabular}

Our specimens have the same diagnostic character as colour and colour pattern recorded before by Thomas (1905 a), Neuhauser and DeBlase (1971). These authors indicated an additional diagnostic character for $P$. $p$. aladdin, a white border, which was found in all of our specimens also.

The measurements of our specimens (see Table 2) agree with five external and nine cranial measurements taken by Neuhauser and DeBlase (1971) from the satisfactory samples series. 
Habitat: The specimens were obtained from a roof covering of a small building in the early July.

During early July, colonies were consisting of about 100 female individuals. Adult females were either pregnant having embrios or nursing mother with twin infants. The colonies did not include adult males.

The daily flight would begin after sunset.

Specimens examined: Total number, 32 from the following localities: Kars province, Aralkk city, The State Farm of Iğdur (I adult 25/8/1968); Van province, Erciş city (30 adult $q$ ㅇ and 1 infant $q$, $3 / 7 / 1979)$.

\section{DISCUSSION}

Although 1 did not have chance to see the type specimen of $P$. p. pipistrellus and that of P.p. aladdin, the original descriptions of them are clear enough to differ them easily. Therefore, I could differ them in my specimens from each other basing on the original descriptions, but unfortunately, I could not obtain any specimen from transition area between the two population, P.p. pipistrellus and P.p. aladdin. So $I$ could not give any marginal records. Thus $I$ have to leave a large blank space between two distribution areas in the map, Fig. 1.

As can be seen in Fig. 1. the four specimens obtained from Bedirge near Antakya and identified as P.p. mediterraneus are located in this blank space that is to say in the transition area between the P.p. pipistrellus and P.p. aladdin.

In this case $P . p$. mediterraneus may be considered as an intermediate form between well defined subspecies, P.p. pipistrellus and P.p. aladdin. This conclusion coincides with that revealed by Neuhauser and DeBlase (1971).

But, Lehmann (1966) identified the four specimens from Bedirge in the vicinity of Antakya as P.p. mediterraneus. However, the taxonomic identity of the four specimens from Bedirge will be clarify exactly after obtaining satisfactory sample series from the transition area between the distribution of the well defined subspecies, P.p. pipistrellus and P.p. aladdin. 


\section{ACKNOWLEDGEMENT}

I am thankful to Prof. Dr. Bahtiye Mursaloğlu for critically reading the manuscript and to The Scientific and Technical Research Council of Turkey (TÜBITTAK) for financial supłort.

\section{LITERATURE CITED}

ALBAYRAK, I., 1985. Researches on Bats of Ankara province (Mammalia: Chiroptera). Communication. Fac. des Scien. de L'univ. d'-Ankara. 3 (C): 1-20.

ANDERSEN, J., 1917. On the determination of age in bats. J. Bombay Nat. Hist. Soc., 25: 249-259.

BAAGOE, H.J., 1977. Age determination in bats (Chiroptera). Vidensk. Meddr nensk. naturh Foren., 140: 53-92.

CABRERA, A., 1904. Ensayo Monografico sobre los Quiropteros de Espana. Mem. Soc. Esp. Hist. Nat., 2: 250-253.

CORBET, G.B., 1978. Tbe Mammals of the Palaearctic Region. A taxonomic Review. British Museum (Nat. Hist.), 38-63.

ELLERMAN, J.R., T.C.S. MORRISON-SCOTT, 1951. Checklist of Palaearetic and Indian mammals, 1758 to 1946. London., 1-810.

HARRISON, D.L., 1964. The Mammals of Arabia. Insectivora, Chiroptera, Primates. London, 1: 1-192.

LEHMANN, E. Vпо, 1966. Taxonomische Bemerkungen zur Säugerausbeute der Kumerloevecshen Orientreisen 1953-1965. Zool. Beitr., (N.F.), 12 (2): 259-265.

LEWIS R.E., D.L. HARRISON, 1962. Notes on Bats from the Republic of Lebanon. Proc. Zool. Soc. Lond. 138 (3): 482-483.

MILLER, G.S., 1897. Pipistrellus pipistrellus. Ann. Mag. Nat. Hist., 20 (6): 383-385.

- 1912. Catalogue of the Mammals of Western Europe (Europe exclusive of Russia) in the collection of the Museum. Brit Mus. Nat. Hist., London, 1-1019.

MURSALOĞLU, B., 1965. Bilimsel Araştırmalar için Omurgalı Numunelerinin Toplanması. Ankara Üniv. Fen. Fak. yayınları, Ankara, 1-60.

NEUHAUSER, N.H., A.F. DeBLASE, 1971. The status of Pipistrellus aladdin Thomas from Central Asia. Mam., 35 (2): 273-282.

SCHREBER, J., 1774. Vespertilio ferrum-equinum, Vespertilio pipistrellus, Vespertilio serotinus. Säugeth., 1 (53): 167-174.

THOMAS, D., 1905a. Pipistrellus aladdin. Abstr. Proc. Zool. Soc., London, 24: 23-25.

- $1905 \mathrm{~b}$. Suggestions for the Nomencluture of the cranial length Measurements and of the cheek-Teeth of Mammals. Proc. Zool. Soc. 18: 191-196. 